\title{
First Evaluation of the Biologically Active Substances and Antioxidant Potential of Regrowth Velvet Antler by means of Multiple Biochemical Assays
}

\author{
Yujiao Tang, ${ }^{1,2,3}$ Byong-Tae Jeon, ${ }^{1,2}$ Yanmei Wang, ${ }^{3}$ Eun-Ju Choi, ${ }^{4}$ Pyo-Jam Park, ${ }^{2,5}$ \\ Hye-Jin Seong, ${ }^{1,2}$ Sang Ho Moon, ${ }^{1,2}$ and Eun-Kyung Kim ${ }^{1,2}$ \\ ${ }^{1}$ Division of Food Bio Science, College of Biomedical and Health Sciences, Konkuk University, Chungju 380-701, Republic of Korea \\ ${ }^{2}$ Korea Nokyong Research Center, Konkuk University, Chungju 380-701, Republic of Korea \\ ${ }^{3}$ Jilin Sino-ROK Institute of Animal Science, Changchun 130-600, China \\ ${ }^{4}$ Division of Sport Science, College of Biomedical and Health Sciences, Konkuk University, Chungju 380-701, Republic of Korea \\ ${ }^{5}$ Department of Biotechnology, Konkuk University, Chungju 380-701, Republic of Korea
}

Correspondence should be addressed to Sang Ho Moon; moon0204@kku.ac.kr and Eun-Kyung Kim; eunkyungkim@kku.ac.kr

Received 31 May 2015; Accepted 2 July 2015

Academic Editor: Patricia Valentao

Copyright (C) 2015 Yujiao Tang et al. This is an open access article distributed under the Creative Commons Attribution License, which permits unrestricted use, distribution, and reproduction in any medium, provided the original work is properly cited.

\begin{abstract}
We investigated the biologically active substances contained in RVA (regrowth velvet antler) by comparing the composition of biologically active substances and antioxidant potential of different antler segments. RVA was subjected to extraction using DW (distilled water). RVA was divided into 3 segments: T-RVA (top RVA), M-RVA (middle RVA), and B-RVA (base RVA). The T-RVA section possessed the greatest amounts of uronic acid $(36.251 \mathrm{mg} / \mathrm{g})$, sulfated GAGs (sulfated glycosaminoglycans) $(555.76 \mathrm{mg} / \mathrm{g})$, sialic acid $(111.276 \mathrm{mg} / \mathrm{g})$, uridine $(0.957 \mathrm{mg} / \mathrm{g})$, uracil $(1.084 \mathrm{mg} / \mathrm{g})$, and hypoxanthine $(1.2631 \mathrm{mg} / \mathrm{g})$. In addition, the T-RVA section possessed the strongest antioxidant capacity as determined by DPPH, $\mathrm{H}_{2} \mathrm{O}_{2}$ (hydrogen peroxide), hydroxyl, and ABTS (2,2' azinobis-3-ethylbenzthiazoline-6-sulphonate) radical scavenging activity as well as FRAP (ferric reducing antioxidant power) and ORAC (oxygen radical absorbance capacity). The values of those were 53.44, 23.09, 34.12, 60.31, and $35.81 \mathrm{TE} / \mu \mathrm{M}$ at $1 \mathrm{mg} / \mathrm{mL}$ and $113.57 \mathrm{TE} / \mu \mathrm{M}$ at $20 \mu \mathrm{g} / \mathrm{mL}$. These results indicate that the T-RVA section possesses the greatest amount of biologically active substances and highest antioxidant potential. This is the first report on the biologically active substances and antioxidant potential of RVA.
\end{abstract}

\section{Introduction}

Velvet antler consists of the cartilaginous, prequalified antlers of moose, elk, and sika deer, which regrow yearly. The growth of deer antlers is one of the fastest types of tissue growth in mammals. Growing antlers contain nerves and blood vessels and are covered with a hairy, skin covering tissue commonly known as "velvet" [1]. Velvet antler is a widely used traditional Asian medicine that has been used clinically in East Asia for millennia to treat various diseases and as a tonic [2]. Velvet antler is generally harvested twice per year. The first velvet antler harvest occurs after 40-45 days of growth, while a second harvest occurs after 50-55 days of regrowth, at which point the harvested velvet antler is known as RVA. Although studies have been conducted on the chemical composition of RVA [3, 4], there have been no comprehensive reports on the composition of biologically active substances and antioxidant potential of RVA.

Numerous studies have demonstrated that free radicals are generated by oxidative damage to biomolecules such as lipids, nucleic acids, proteins, and carbohydrates [57]. Overproduction of free radicals and reactive oxygen species is believed to be associated with cellular and tissue pathogenesis, which leads to several chronic diseases such as cancer, diabetes mellitus, and neurodegenerative and inflammatory diseases [8]. Many medical reports and clinical observations convincingly show that disease-resistance can be conferred by enhancing antioxidative processes [9-14]. 
Therefore, antioxidant supplementation could prevent or inhibit oxidative stress induced by ROS. Antioxidants terminate free radical chain reactions by removing free radical intermediates while inhibiting other oxidation reactions. Because of the clinical potential of antioxidants, significant interest has been focusing on the development of natural antioxidants that are safe and effective.

In this study, RVA was subjected to extraction by DW to allow determination of its constituent biologically active substances, including uronic acid, sulfated GAGs, sialic acid, uracil, hypoxanthine, and uridine. In addition, the antioxidant activities of RVA were determined by assessing DPPH, $\mathrm{H}_{2} \mathrm{O}_{2}$, hydroxyl, and ABTS radical scavenging activity as well as FRAP and ORAC.

\section{Materials and Methods}

2.1. Materials. Seven specimens of sika deer (Cervus nippon) RVA were collected at the same farm (Fanrong farm, China). Carbazole, sodium tetraborate, dimethylmethylene blue, glycine, sodium thiosulfate, acetoacetanilide, uracil, hypoxanthine, uridine, DPPH, ABTS, potassium persulfate, TPTZ (2,4,6-tris(2-pyridyl)-s-triazine), FL, and AAPH (2,2' azobis(2-amidinopropane) dihydrochloride) were purchased from Sigma-Aldrich (St. Louis, MO, USA).

2.2. Preparation of Samples. The RVA specimens were divided into 3 sections, T-RVA, M-RVA, and B-RVA, lyophilized and homogenized with a grinder. Next, $10 \mathrm{~g}$ of each segment was added to $100 \mathrm{~mL}$ of DW and subjected to extraction in boiling DW for $1 \mathrm{~h}$. The RVA extracts were filtered $(0.25 \mu \mathrm{m}$ pore size) and lyophilized (yields: T-RVA, $3.87 \%$; M-RVA, 3.61\%; B-RVA, 2.66\%) in a freeze dryer for 5 days.

\subsection{Analysis of Bioactive Compounds}

2.3.1. Uronic Acid. Uronic acid content was determined by the carbazole reaction [15]. Briefly, a $50 \mu \mathrm{L}$ serial dilution of the standards or samples was placed in a 96-well plate, after which $200 \mu \mathrm{L}$ of $25 \mathrm{mM}$ sodium tetraborate in sulfuric acid was added to each well. The plate was heated for $10 \mathrm{~min}$ at $100^{\circ} \mathrm{C}$ in an oven. After cooling at room temperature for $15 \mathrm{~min}, 50 \mu \mathrm{L}$ of $0.125 \%$ carbazole in absolute ethanol was carefully added. After heating at $100^{\circ} \mathrm{C}$ for $10 \mathrm{~min}$ in an oven and cooling at room temperature for $15 \mathrm{~min}$, the plate was read in a microplate reader at a wavelength of $550 \mathrm{~nm}$.

2.3.2. Sulfated GAGs. GAGs content was determined by the DMB (dimethylmethylene blue) dye binding method [16]. Briefly, the color reagent was prepared by dissolving $0.008 \mathrm{~g}$ of DMB in a solution containing $1.185 \mathrm{~g} \mathrm{NaCl}, 1.520 \mathrm{~g}$ glycine, $0.47 \mathrm{~mL} \mathrm{HCl}(12 \mathrm{M})$, and $500 \mathrm{~mL}$ DW. Each sample was mixed into $1 \mathrm{~mL}$ of color reagent and the absorbance was read immediately at $525 \mathrm{~nm}$.

2.3.3. Sialic Acid. Sialic acid content was determined based on the procedures described by Matsuno and Suzuki [17]. All solutions were precooled in an ice bath. Sodium periodate solution $(10 \mathrm{mM}, 20 \mu \mathrm{L})$ was added to $200 \mu \mathrm{L}$ of a glycoconjugate sample in a $15 \mathrm{~mL}$ polypropylene test tube. The solution was chilled in an ice bath for $45 \mathrm{~min}$. The reaction was terminated by the addition of $100 \mu \mathrm{L}$ of $50 \mathrm{mM}$ sodium thiosulfate solution. Next, $500 \mu \mathrm{L}$ of $4.0 \mathrm{M}$ ammonium acetate ( $\mathrm{pH} 7.5$ ) and $400 \mu \mathrm{L}$ of ethanolic solution of $100 \mathrm{mM}$ acetoacetanilide were added to the solution, which was left standing for $10 \mathrm{~min}$ at room temperature. The fluorescence intensity of the solution was measured at $471 \mathrm{~nm}$ with an excitation wavelength of $388 \mathrm{~nm}$.

2.3.4. Uracil, Hypoxanthine, and Uridine. Uracil, hypoxanthine, and uridine were determined as described previously [18]. $1 \mathrm{mg}$ of the DW extract was dissolved in $1 \mathrm{~mL}$ of $3 \%$ methanol solution, after which $1 \mathrm{~mL}$ of the resulting solution was filtered for HPLC analysis. The analysis was performed on an HPLC system equipped with an isocratic pump (Kyoto, Japan) and RI (refractive index) detector (Lab Alliance, model 500). The separation was conducted on a ZORBAX Eclipse Plus C18 column $(4.6 \times 150 \mathrm{~mm}, 5 \mu \mathrm{m}$, Agilent Technologies, USA). The mobile phase was $0.07 \%$ acetic acid methanol water $(3: 97, \mathrm{v} / \mathrm{v} ; \mathrm{pH} 3.5)$ at a flow rate of $1.0 \mathrm{~mL} / \mathrm{min}$. A series of standards of uracil, hypoxanthine, and uridine in the range of $0.625-40.00 \mathrm{ppm}$ were prepared in the mobile phase. Quantification was carried out by integration of the peak areas using external standard calibration. A linear response with a correlation coefficient of 0.999 $(n=6)$ was obtained for the standards. For all experiments, the extracts and standards were filtered through a $0.45 \mu \mathrm{m}$ cellulose ester membrane before injection into the HPLC system. Detection was performed at a wavelength of $254 \mathrm{~nm}$.

\subsection{Antioxidant Activity}

2.4.1. DPPH Radical Scavenging Activity. The DPPH scavenging activity of each antler extract was measured according to a slightly modified version of the method of Blois [19]. DPPH solutions $\left(1.5 \times 10^{-4} \mathrm{M}, 100 \mu \mathrm{L}\right)$ were mixed with and without each extract $(100 \mu \mathrm{L})$, after which the mixtures were incubated at room temperature for $30 \mathrm{~min}$. After standing for $30 \mathrm{~min}$, absorbance was recorded at $540 \mathrm{~nm}$ using a microplate reader. The scavenging activity was calculated as a percentage using the following equation:

$$
\text { Inhibition }(\%)=\frac{\left(A_{\text {control }}-A_{\text {sample }}\right)}{A_{\text {control }}} \times 100 \text {, }
$$

where $A_{\text {control }}$ was the absorbance of the reaction mixture without an RVA sample and $A_{\text {sample }}$ was the absorbance of the reaction mixture with an RVA sample.

2.4.2. Hydrogen Peroxide Radical Scavenging Activity. Hydrogen peroxide scavenging activity was determined according to the method of Muller [20]. A $100 \mu \mathrm{L}$ of $0.1 \mathrm{M}$ phosphate buffer ( $\mathrm{pH}$ 5.0) was mixed with each extract in a 96-microwell plate. A $20 \mu \mathrm{L}$ of hydrogen peroxide was added to the mixture and then incubated at $37^{\circ} \mathrm{C}$ for $5 \mathrm{~min}$. After the incubation, $30 \mu \mathrm{L}$ of $1.25 \mathrm{mM}$ ABTS and $30 \mu \mathrm{L}$ of peroxidase ( $1 \mathrm{unit} / \mathrm{mL}$ ) were added to the mixture and then incubated 
at $37^{\circ} \mathrm{C}$ for $10 \mathrm{~min}$. The absorbance was recorded at $405 \mathrm{~nm}$ by microplate reader and the percentage of scavenging activity was calculated using (1).

2.4.3. Hydroxyl Radical Scavenging Activity. The hydroxyl radical scavenging activity of each antler extract was determined according to the method of Chung et al. [21]. Hydroxyl radicals were generated by the Fenton reaction in the presence of $\mathrm{FeSO}_{4}$. A reaction mixture containing $0.1 \mathrm{~mL}$ of $10 \mathrm{mM} \mathrm{FeSO}_{4}, 10 \mathrm{mM}$ EDTA, and $10 \mathrm{mM}$ 2-deoxyribose was mixed with $0.1 \mathrm{~mL}$ of the extract solution, after which $0.1 \mathrm{M}$ phosphate buffer ( $\mathrm{pH}$ 7.4) was added to the reaction mixture to reach a total volume of $0.9 \mathrm{~mL}$. Subsequently, $0.1 \mathrm{~mL}$ of $10 \mathrm{mM} \mathrm{H}_{2} \mathrm{O}_{2}$ was added to the reaction mixture, which was incubated at $37^{\circ} \mathrm{C}$ for $4 \mathrm{~h}$. After incubation, $0.5 \mathrm{~mL}$ of $2.8 \%$ TCA and $1.0 \%$ TBA were added to each mixture, after which each mixture was placed in a boiling water bath for $10 \mathrm{~min}$. Absorbance was measured at $532 \mathrm{~nm}$. Hydroxyl radical scavenging activity was calculated as a percentage using (1).

2.4.4. ABTS Radical Scavenging Activity. The ABTS scavenging activity of each antler extract was assessed following the method of Arnao et al. [22]. Stock solutions included ABTS ${ }^{\circ+}$ solution and potassium persulfate solutions. A working solution was prepared by mixing the 2 stock solutions in equal quantities and allowing them to react for $12 \mathrm{~h}$. The working solution was diluted with fresh $\mathrm{ABTS}^{\circ+}$ solution and mixed with or without each extract. After incubation for $2 \mathrm{~h}$, the absorbance of each solution was recorded at $735 \mathrm{~nm}$. The scavenging activity was calculated as a percentage using (1).

2.4.5. FRAP Assay. The FRAP assay was performed according to the method of Benzie and Strain [23]. Fresh working solution was prepared by mixing acetate buffer, TPTZ solution, and $\mathrm{FeCl}_{3} \cdot 6 \mathrm{H}_{2} \mathrm{O}$ solution and warmed at $37^{\circ} \mathrm{C}$ before use. Each extract was allowed to react with the FRAP solution in a dark room at room temperature for $30 \mathrm{~min}$. The absorbance of the colored product was measured at $595 \mathrm{~nm}$. Scavenging activity was calculated as a percentage using (1).

2.4.6. ORAC Assay. For ORAC assay, the method of Ou et al. was used with some slightly modification [24]. The working solution of FL and AAPH radical was prepared daily. Sample, blank, or standard was placed in 96-microwell plate, and the plate was heated to $37^{\circ} \mathrm{C}$ for $15 \mathrm{~min}$ prior to the addition of AAPH. The fluorescence was measured immediately after the AAPH addition and measurements with fluorescence filters for an excitation wavelength of $485 \mathrm{~nm}$ and an emission wavelength of $535 \mathrm{~nm}$ were taken every $5 \mathrm{~min}$ until the relative fluorescence intensity was less than $5 \%$ of the value of the initial reading.

The ORAC values, expressed as $\mu \mathrm{M}$ Trolox equivalents ( $\mu \mathrm{MTE} / \mathrm{mg}$ ) were calculated by applying the following formula:

$$
\begin{aligned}
& \operatorname{ORAC}(\mu \mathrm{MTE}) \\
& =\frac{\left(C_{\text {Trolox }} \times\left(\mathrm{AUC}_{\text {sample }}-\mathrm{AUC}_{\text {blank }}\right) \times k\right)}{\left(\mathrm{AUC}_{\text {sample }}-\mathrm{AUC}_{\text {blank }}\right)},
\end{aligned}
$$

where $C_{\text {Trolox }}$ is the concentration of Trolox $(20 \mu \mathrm{M}), k$ is the sample dilution factor, and AUC is the area below the fluorescence decay curve of the sample, blank, and Trolox, respectively, calculated by applying the following formula in a Microsoft Excel spreadsheet (Microsoft, Washington, USA):

$$
\mathrm{AUC}=\left(0.5+\frac{f_{5}}{f_{0}}+\frac{f_{10}}{f_{0}}+\cdots+f_{n}+\frac{5}{f_{0}}\right) \times 5,
$$

where $f_{0}$ is the initial fluorescence and $f_{n}$ is the fluorescence at time $n$.

2.5. Statistical Analysis. The results shown are summaries of the data from at least 3 experiments. All data are presented as mean \pm SEM (standard error of the mean). Statistical analyses were performed using SAS statistical software (SAS Institute, Inc., Cary, NC, USA). Treatment effects were analyzed using one-way ANOVA followed by Dunnett's multiple range test. Results of $P<0.05$ indicated statistical significance.

\section{Results and Discussion}

3.1. Bioactive Composition. The biologically active substances contained in the 3 RVA segments, including uronic acid, sulfated GAGs, sialic acid, uridine, uracil, and hypoxanthine, are listed in Tables 1 and 2.

The uronic acid content, sulfated GAGs content, and sialic acid content of the T-RVA and M-RVA sections were significantly greater than those of the B-RVA section $(P<$ $0.05)$. The DW extract of the T-RVA section contained $36.25 \mathrm{mg} / \mathrm{g}$ uronic acid, $555.76 \mathrm{mg} / \mathrm{g}$ sulfated GAGs, and $111.28 \mathrm{mg} / \mathrm{g}$ sialic acid (Table 1). The DW extract of the RVA contained $0.957 \mathrm{mg} / \mathrm{g}$ uridine, $1.084 \mathrm{mg} / \mathrm{g}$ uracil, and $1.263 \mathrm{mg} / \mathrm{g}$ hypoxanthine (Table 2).

Uronic acid has been reported to improve circulation and decrease stroke risk [25]; therefore, our chemical analyses indicate that the DW extract of T-RVA might possess similar activities. Sulfated GAGs, particularly CS (chondroitin sulfate), are of particular interest to physicians and pharmacists. Sulfated GAGs are composed of units of amino sugar, including $\mathrm{D}$-glucosamine and $\mathrm{D}$-galactosamine, and bond with core proteins to form proteoglycans. Cartilage proteoglycans regulate water retention and are integral to the differentiation and proliferation of chondrocytes. The most prominent sulfated GAG in velvet antler tissue is chondroitin sulfate [26]. Sialic acid is a water soluble component that was efficiently extracted by DW and showed significant accumulation in the T-RVA section. Our findings are similar to those of a previous report [27], which showed that the TRVA, or "wax piece," contains sialic acid levels higher than those of other antler regions. Uracil is a primary mediator of MAO (monoamine oxidase) inhibition by velvet antler extract [28]. Our data indicate that the T-RVA section may contribute the majority of the inhibitory effect on MAO activity produced by velvet antler. In a report by Wang et al. [29] aimed at identifying the active compound in velvet antler responsible for inhibiting MAO-B activity, the author suggested that the main antiaging compound in velvet antler is hypoxanthine. Zhou et al. [28] showed that uridine was 
TABLE 1: Sulfated GAGs, sialic acid, and uronic acid contents of regrowth velvet antler extracts.

\begin{tabular}{lccc}
\hline & $\begin{array}{c}\text { T-RVA } \\
\mathrm{mg} / \mathrm{g}\end{array}$ & $\begin{array}{c}\text { M-RVA } \\
\mathrm{mg} / \mathrm{g}\end{array}$ & $\begin{array}{c}\text { B-RVA } \\
\mathrm{mg} / \mathrm{g}\end{array}$ \\
\hline Sulfated GAGs & $555.76 \pm 12.48$ & $369.30 \pm 19.81$ & $228.98 \pm 24.42$ \\
Sialic acid & $111.28 \pm 4.27$ & $79.50 \pm 5.20$ & $72.96 \pm 1.50$ \\
Uronic acid & $36.25 \pm 2.96$ & $25.90 \pm 2.29$ & $23.11 \pm 2.40$ \\
\hline
\end{tabular}

TABLE 2: Hypoxanthine, uridine, and uracil contents of regrowth velvet antler extracts.

\begin{tabular}{lccc}
\hline & $\begin{array}{c}\text { T-RVA } \\
\mathrm{mg} / \mathrm{g}\end{array}$ & $\begin{array}{c}\text { M-RVA } \\
\mathrm{mg} / \mathrm{g}\end{array}$ & $\begin{array}{c}\text { B-RVA } \\
\mathrm{mg} / \mathrm{g}\end{array}$ \\
\hline Hypoxanthine & $1.08 \pm 0.03$ & $1.00 \pm 0.01$ & $0.92 \pm 0.01$ \\
Uridine & $1.26 \pm 0.03$ & $1.14 \pm 0.04$ & $1.06 \pm 0.03$ \\
Uracil & $0.96 \pm 0.08$ & $0.092 \pm 0.03$ & $0.845 \pm 0.04$ \\
\hline
\end{tabular}

responsible for $34.75 \%$ of the $\mathrm{Fe}^{2+}$-chelating activity of velvet antler. Therefore, the DW extract of T-RVA is expected to show strong antioxidant activity due to its abundance of uridine. Zhou and $\mathrm{Li}$ [18] investigated the amounts of uridine, uracil, and hypoxanthine from ethanol extracted velvet antler, and the values were $3.7,3.6$ and $3.9 \mathrm{mg} / \mathrm{g}$, respectively. Their values were higher than ours. This may be attributed to extraction method.

3.2. Antioxidant Activity. The antioxidant activities of RVA may not be attributed to a single mechanism. Therefore, 6 methods were used to evaluate different aspects of the antioxidant activities of RVA.

The antioxidant activities of the DW extracts of RVA were evaluated by assessing DPPH, $\mathrm{H}_{2} \mathrm{O}_{2}$, ABTS, and hydroxyl radical scavenging activity. In addition, FRAP and ORAC were estimated.

The antioxidant activity of the DW extract of T-RVA was significantly better than those of the M-RVA and B-RVA sections $(P<0.05)$ and appeared to be dose-dependent. The DPPH radical scavenging activity was highest for the T-RVA section $\left(53.44 \mu \mathrm{MTE} / \mathrm{mg}, \mathrm{IC}_{50} 0.853 \mathrm{mg} / \mathrm{mL}\right)$ and lowest for the B-RVA section (Figure 1). $\mathrm{H}_{2} \mathrm{O}_{2}(32.20 \mu \mathrm{MTE} / \mathrm{mg}$; Figure 2) and ABTS $(60.31 \mu \mathrm{M} \mathrm{TE} / \mathrm{mg}$; Figure 3$)$ radical scavenging activities were also highest for the T-RVA section. The hydroxyl radical scavenging activity was highest for the T-RVA section $(23.09 \mu \mathrm{MTE} / \mathrm{mg})$, whereas the activities of M-RVA and B-RVA were similar (Figure 4). The T-RVA section was the most effective section in the FRAP assay $(35.81 \mu \mathrm{MTE} / \mathrm{mg})$, whereas the activities of B-RVA and M-RVA were similar (Figure 5). In the ORAC assay, 1,000 $\mathrm{mg} / \mathrm{mL}$ T-RVA showed excellent activity (121.58 $\mu \mathrm{M} \mathrm{TE} / \mathrm{mg}$ ) (Figure 6).

DPPH radical scavenging activity is often used as a method of evaluating antioxidant activity. DPPH is a stable radical that accepts an electron and/or hydrogen radical from donor molecules to form a stable diamagnetic molecule. Therefore, the extracts of velvet antler may have provided an electron and/or hydrogen radical to neutralize DPPH [30]. In a report by Lee and Chung [31], the DPPH radical scavenging

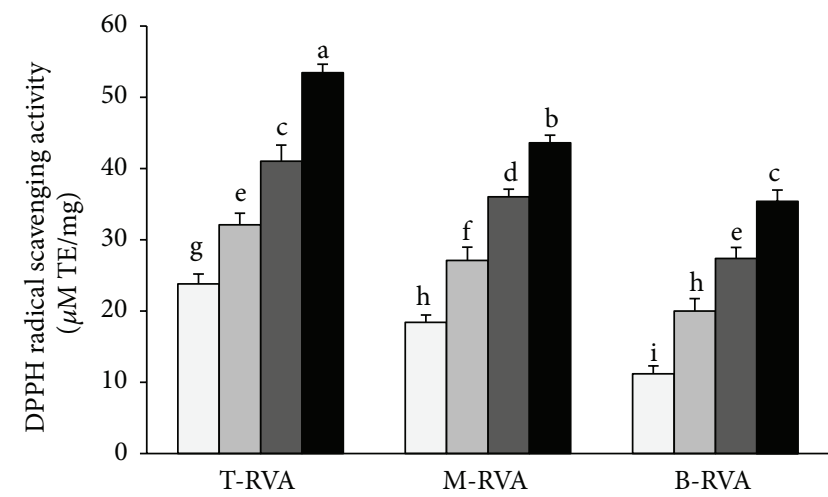

FIGURE 1: The effect of RVA on DPPH radical scavenging activity. ${ }^{\mathrm{a}-\mathrm{i}}$ Values not sharing a common letter are significantly different at $P<0.05$ by Dunnett's multiple range tests. Light gray square, $125 \mu \mathrm{g} / \mathrm{mL}$; gray square, $250 \mu \mathrm{g} / \mathrm{mL}$; dark grey square, $500 \mu \mathrm{g} / \mathrm{mL}$; black square, $1,000 \mu \mathrm{g} / \mathrm{mL}$.

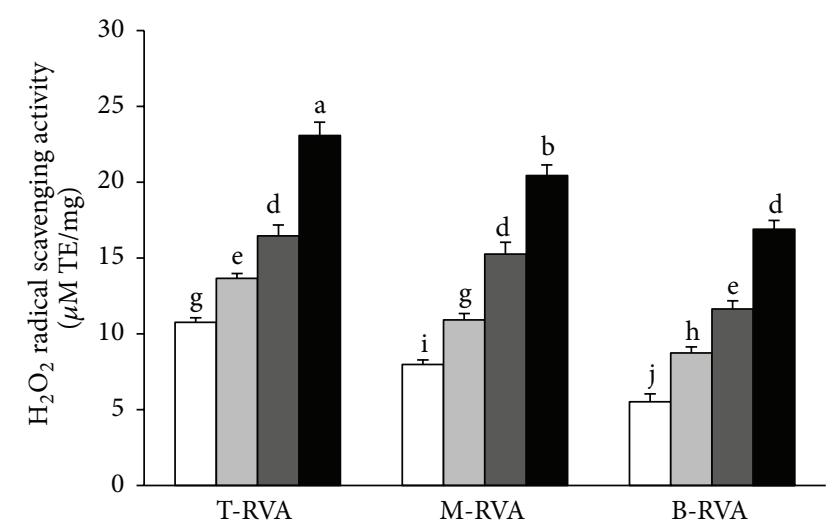

FIgURE 2: The effect of RVA on $\mathrm{H}_{2} \mathrm{O}_{2}$ radical scavenging activity. ${ }^{\mathrm{a}-\mathrm{i}}$ Values not sharing a common letter are significantly different at $P<0.05$ by Dunnett's multiple range tests. Light gray square, $125 \mu \mathrm{g} / \mathrm{mL}$; gray square, $250 \mu \mathrm{g} / \mathrm{mL}$; dark grey square, $500 \mu \mathrm{g} / \mathrm{mL}$; black square, $1,000 \mu \mathrm{g} / \mathrm{mL}$.

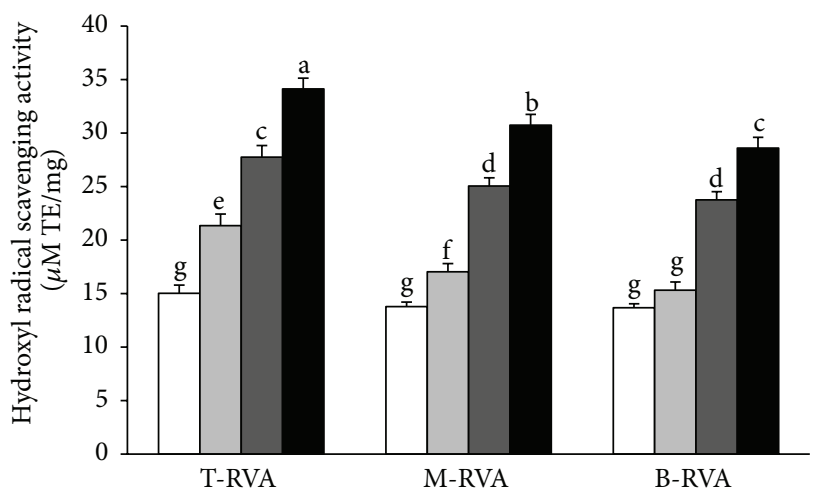

FIGURE 3: The effect of RVA on hydroxyl radical scavenging activity. ${ }^{\mathrm{a}-\mathrm{g}}$ Values not sharing a common letter are significantly different at $P<0.05$ by Dunnett's multiple range tests. Light gray square, $125 \mu \mathrm{g} / \mathrm{mL}$; gray square, $250 \mu \mathrm{g} / \mathrm{mL}$; dark grey square, $500 \mu \mathrm{g} / \mathrm{mL}$; black square, $1,000 \mu \mathrm{g} / \mathrm{mL}$. 


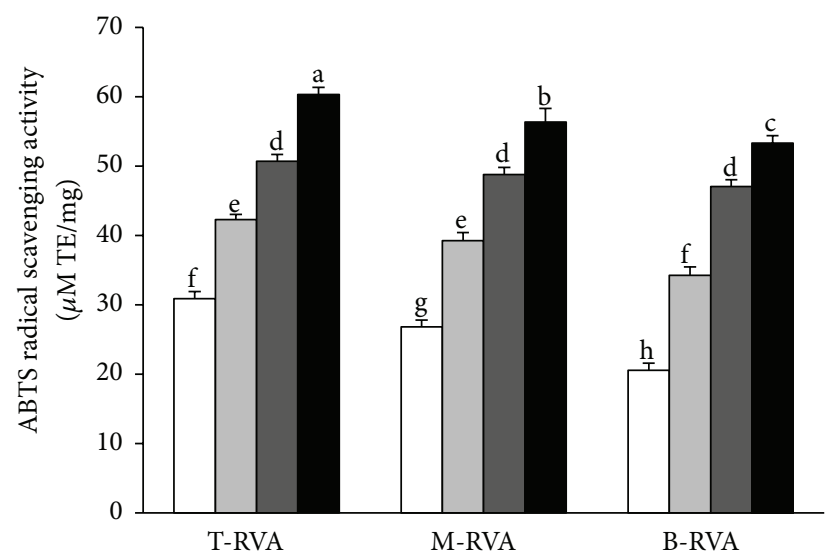

FIgURE 4: The effect of RVA on ABYS radical scavenging activity. ${ }^{\mathrm{a}-\mathrm{g}}$ Values not sharing a common letter are significantly different at $P<0.05$ by Dunnett's multiple range tests. Light gray square, $125 \mu \mathrm{g} / \mathrm{mL}$; gray square, $250 \mu \mathrm{g} / \mathrm{mL}$; dark grey square, $500 \mu \mathrm{g} / \mathrm{mL}$; black square, $1,000 \mu \mathrm{g} / \mathrm{mL}$.

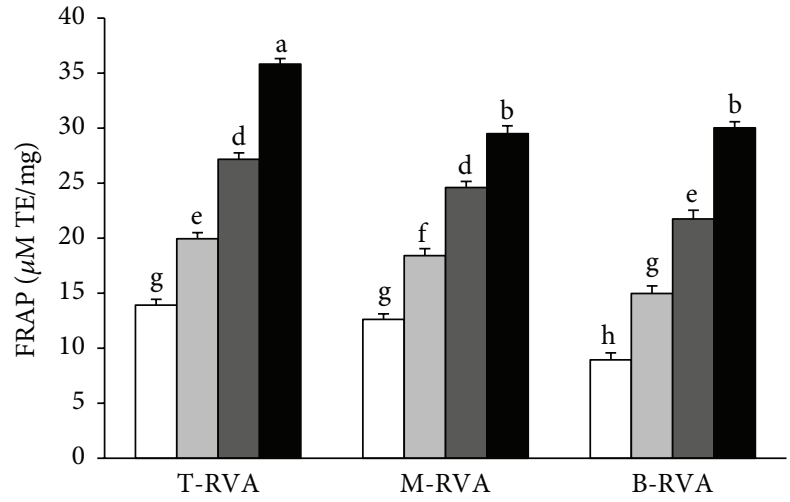

FIGURE 5: The effect of RVA on FRAP assay. ${ }^{a-g}$ Values not sharing a common letter are significantly different at $P<0.05$ by Dunnett's multiple range tests. Light gray square, $125 \mu \mathrm{g} / \mathrm{mL}$; gray square, $250 \mu \mathrm{g} / \mathrm{mL}$; dark grey square, $500 \mu \mathrm{g} / \mathrm{mL}$; black square, $1,000 \mu \mathrm{g} / \mathrm{mL}$.

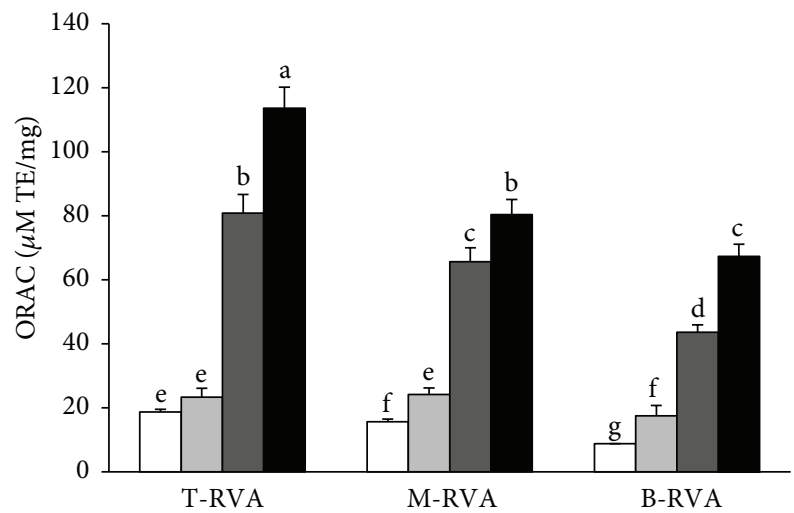

FIgURE 6: The effect of RVA on ORAC. ${ }^{a-g}$ Values not sharing a common letter are significantly different at $P<0.05$ by Dunnett's multiple range tests. Light gray square, $125 \mu \mathrm{g} / \mathrm{mL}$; gray square, $250 \mu \mathrm{g} / \mathrm{mL}$; dark grey square, $500 \mu \mathrm{g} / \mathrm{mL}$; black square, $1,000 \mu \mathrm{g} / \mathrm{mL}$. activity of velvet antler extract obtained from the upper section was reported to be $67.1 \%$ at an extract concentration of $100 \mathrm{mg} / \mathrm{mL}$, which was lower than the activity measured in our analysis. $\mathrm{H}_{2} \mathrm{O}_{2}$ is a reactive nonradical and a clinically important compound due to its ability to penetrate biological membranes. $\mathrm{H}_{2} \mathrm{O}_{2}$ can be converted into more reactive species, such as singlet oxygen and hydroxyl radicals, thereby causing lipid peroxidation or toxicity to cells. Therefore, scavenging of hydrogen peroxide can decrease prooxidants' levels. Our analysis of $\mathrm{H}_{2} \mathrm{O}_{2}$ scavenging by velvet antler produced results similar to those reported by Je et al. [30]. Hydroxyl radicals are extremely reactive and easily react with amino acids, DNA, and membrane components. In this study, the hydroxyl radical scavenging activity of RVA was higher than that of velvet antler as reported by Je et al. [32]. In addition, our analysis of ABTS radical scavenging activity by RVA identified activity higher than that reported by Zhao et al. [33]. The FRAP assay treats the antioxidants contained in the samples as reductants in a redox-linked colorimetric reaction, allowing assessment of the reducing power of antioxidants [34]. Zhao et al. [33] reported activity of $85.8 \pm 0.02 \%$ by $5 \mathrm{mg} / \mathrm{mL}$ velvet antler extract in the FARP assay, which was lower than the activity measured in our analysis. The ORAC assay has been applied extensively to evaluate the antioxidant activities of fruits, vegetables, leaves, stems, herbs, and spices. As a result, the ORAC assay is commonly mentioned in scientific publications and health food publications [35]. However, the antioxidant activity of RVA has not been evaluated using the ORAC assay. Therefore, this is the first report of an assessment of the antioxidant activity of RVA using the ORAC assay. ORAC value of gallic acid was shown $161 \pm 4.8$ by Zulueta et al. [36], which was higher than the activity of RVA found in our study.

\section{Conclusions}

In the present study, we provided the first comprehensive evaluation of the biologically active substances of RVA and the antioxidant potential of different RVA segments. Future studies are required to further elucidate the other biological activities of the T-RVA, M-RVA, and B-RVA sections and the biological mechanisms underlying their effects.

\section{Conflict of Interests}

The authors declare that there is no conflict of interests regarding the publication of this paper.

\section{Acknowledgment}

This paper was supported by Konkuk University in 2015.

\section{References}

[1] C. Li, "Development of deer antler model for biomedical research," Recent Advances \& Research Updates, vol. 4, no. 2, pp. 255-274, 2003.

[2] Z. Q. Zhang, Y. Zhang, B. X. Wang, H. O. Zhou, Y. Wang, and H. Zhang, "Purification and partial characterization of 
anti-inflammatory peptide from pilose antler of Cervus nippon Temminck," Acta Pharmaceutica Sinica, vol. 27, no. 5, pp. 321324, 1992.

[3] Z. F. Ma, D. S. Zhao, Q. D. Zhou, and S. Sun, "Study on raising yield of reproductive pilose antler of sika deer," Journal of Northeast Forestry University, vol. 22, no. 6, pp. 41-47, 1994.

[4] J. F. He, Y. Z. Liu, S. B. Zhu, and L. Shang, "Study on increasing quality and quantity of reborn antlers of cervus elaphuslinnaeus and cervus Nippon hortulorun, swinchone," Natural Science Journal of Harbin Normal University, vol. 20, no. 4, pp. 91-94, 2004.

[5] D. A. Butterfield, A. Castegna, C. M. Lauderback, and J. Drake, "Evidence that amyloid beta-peptide-induced lipid peroxidation and its sequelae in Alzheimer's disease brain contribute to neuronal death," Neurobiology of Aging, vol. 23, no. 5, pp. 655664, 2002.

[6] W. A. Pryor and N. Y. Ann, "Free radical biology: xenobiotics, cancer, and aging," Annals of the New York Academy of Sciences, vol. 393, no. 1, pp. 1-22, 1982.

[7] E.-K. Kim, S.-J. Lee, J.-W. Hwang et al., "In vitro investigation on antioxidative effect of Inonotus obliquus extracts against oxidative stress on PC12 cells," Journal of the Korean Society for Applied Biological Chemistry, vol. 54, no. 1, pp. 112-117, 2011.

[8] J.-W. Hwang, E.-K. Kim, S.-J. Lee et al., "Antioxidant activity and protective effect of anthocyanin oligomers on $\mathrm{H}_{2} \mathrm{O}_{2}$-triggered G2/M arrest in retinal cells," Journal of Agricultural and Food Chemistry, vol. 60, no. 17, pp. 4282-4288, 2012.

[9] B. R. Bhavnani, "Pharmacology of hormonal therapeutic agents," in The Menopause Comprehensive Management, B. A. Eskin, Ed., pp. 229-256, Parthenon Press, New York, NY, USA, 2000.

[10] S. S. Ditchkoff, L. J. Spicer, R. E. Masters, and R. L. Lochmiller, "Concentrations of insulin-like growth factor-I in adult male white-tailed deer (Odocoileus virginianus): associations with serum testosterone, morphometrics and age during and after the breeding season," Comparative Biochemistry and Physiology A: Physiology, vol. 129, no. 4, pp. 887-895, 2001.

[11] J. Á. Gómez, A. J. García, T. Landete-Castillejos, and L. Gallego, "Effect of advancing births on testosterone until 2.5 years of age and puberty in Iberian red deer (Cervus elaphus hispanicus)," Animal Reproduction Science, vol. 96, no. 1-2, pp. 79-88, 2006.

[12] C. Li, Z. Jiang, G. Jiang, and J. Fang, "Seasonal changes of reproductive behavior and fecal steroid concentrations in Père David's deer," Hormones and Behavior, vol. 40, no. 4, pp. 518525, 2001.

[13] Y.-J. Li, T.-H. Kim, H. B. Kwak, Z. H. Lee, S.-Y. Lee, and G.J. Jhon, "Chloroform extract of deer antler inhibits osteoclast differentiation and bone resorption," Journal of Ethnopharmacology, vol. 113, no. 2, pp. 191-198, 2007.

[14] H. H. Sunwoo, T. Nakano, and J. S. Sim, "Effect of water-soluble extract from antler of wapiti (Cervus elaphus) on the growth of fibroblasts," Canadian Journal of Animal Science, vol. 77, no. 2, pp. 343-345, 1997.

[15] M. Cesaretti, E. Luppi, F. Maccari, and N. Volpi, "A 96-well assay for uronic acid carbazole reaction," Carbohydrate Polymers, vol. 54, no. 1, pp. 59-61, 2003.

[16] R. W. Farndale, D. J. Buttle, and A. J. Barrett, "Improved quantitation and discrimination of sulphated glycosaminoglycans by use of dimethylmethylene blue," Biochimica Biophysica Acta, vol. 883 , no. 2 , pp. $173-177,1986$.
[17] K. Matsuno and S. Suzuki, "Simple fluorimetric method for quantification of sialic acids in glycoproteins," Analytical Biochemistry, vol. 375, no. 1, pp. 53-59, 2008.

[18] R. Zhou and S. F. Li, "In vitro antioxidant analysis and characterisation of antler velvet extract," Food Chemistry, vol. 114, no. 4, pp. 1321-1327, 2009.

[19] M. S. Blois, "Antioxidant determinations by the use of a stable free radical," Nature, vol. 181, no. 4617, pp. 1199-1200, 1958.

[20] H. E. Muller, "Detection of hydrogen peroxide produced by microorganism on ABTS-peroxidase medium," Zentralblatt für Bakteriologie, Mikrobiologie und Hygiene, vol. 259, no. 2, pp. 151158, 1985.

[21] S.-K. Chung, T. Osawa, and S. Kawakishi, "Hydroxyl radicalscavenging effects of spices and scavengers from brown mustard (Brassica nigra)," Bioscience, Biotechnology and Biochemistry, vol. 61, no. 1, pp. 118-123, 1997.

[22] M. B. Arnao, A. Cano, and M. Acosta, "The hydrophilic and lipophilic contribution to total antioxidant activity," Food Chemistry, vol. 73, no. 2, pp. 239-244, 2001.

[23] I. F. F. Benzie and J. J. Strain, "The ferric reducing ability of plasma (FRAP) as a measure of 'antioxidant power': the FRAP assay," Analytical Biochemistry, vol. 239, no. 1, pp. 70-76, 1996.

[24] B. Ou, M. Hampsch-Woodill, and R. L. Prior, "Development and validation of an improved oxygen radical absorbance capacity assay using fluorescein as the fluorescent probe," Journal of Agricultural and Food Chemistry, vol. 49, no. 10, pp. 4619-4626, 2001.

[25] M. A. Moskowitz, E. H. Lo, and C. Iadecola, "The science of stroke: mechanisms in search of treatments," Neuron, vol. 67, no. 2, pp. 181-198, 2010.

[26] Y. W. Ha, B. T. Jeon, S. H. Moon et al., "Characterization of heparan sulfate from the unossified antler of Cervus elaphus," Carbohydrate Research, vol. 340, no. 3, pp. 411-416, 2005.

[27] B. Jeon, S. Kim, S. Lee et al., "Effect of antler growth period on the chemical composition of velvet antler in sika deer (Cervus nippon)," Mammalian Biology, vol. 74, no. 5, pp. 374-380, 2009.

[28] R. Zhou, J. Wang, S. Li, and Y. Liu, "Supercritical fluid extraction of monoamine oxidase inhibitor from antler velvet," Separation and Purification Technology, vol. 65, no. 3, pp. 275-281, 2009.

[29] B. X. Wang, X. H. Zhao, X. W. Yang et al., "Inhibition of lipid peroxidation of deer antler (Rokujo) extract in vivo and in vitro," Journal of Medical and Pharmaceutical Society for WAKAN-YAKU, vol. 5, pp. 123-128, 1988.

[30] J. Y. Je, P. J. Park, D. H. Lim, B. T. Jeon, K. H. Kho, and C. B. Ahn, "Antioxidant, anti-acetylcholinesterase and composition of biochemical components of Russian deer velvet antler extracts," Korean Journal for Food Science of Animal Resources, vol. 31, no. 3, pp. 349-355, 2011.

[31] K. A. Lee and H. Y. Chung, "The biological activity of deer antler extract in vitro," The Korean Journal of Food and Nutrition, vol. 20, no. 2, pp. 114-119, 2007.

[32] J.-Y. Je, P.-J. Park, E.-K. Kim et al., "Composition of biologically active substances and antioxidant activity of New Zealand deer velvet antler extracts," Korean Journal for Food Science of Animal Resources, vol. 30, no. 1, pp. 20-27, 2010.

[33] L. Zhao, Y.-C. Luo, C.-T. Wang, and B.-P. Ji, "Antioxidant activity of protein hydrolysates from aqueous extract of velvet antler (Cervus elaphus) as influenced by molecular weight and enzymes," Natural Product Communications, vol. 6, no. 11, pp. 1683-1688, 2011. 
[34] S.-Q. Huang, S. D. Ding, and L. P. Fan, "Antioxidant activities of five polysaccharides from Inonotus obliquus," International Journal of Biological Macromolecules, vol. 50, no. 5, pp. 1183-1187, 2012.

[35] K. Thaipong, U. Boonprakob, K. Crosby, L. Cisneros-Zevallos, and D. H. Byrne, "Comparison of ABTS, DPPH, FRAP, and ORAC assays for estimating antioxidant activity from guava fruit extracts," Journal of Food Composition and Analysis, vol. 19, no. 6-7, pp. 669-675, 2006.

[36] A. Zulueta, M. J. Esteve, and A. Frígola, "ORAC and TEAC assays comparison to measure the antioxidant capacity of food products," Food Chemistry, vol. 114, no. 1, pp. 310-316, 2009. 

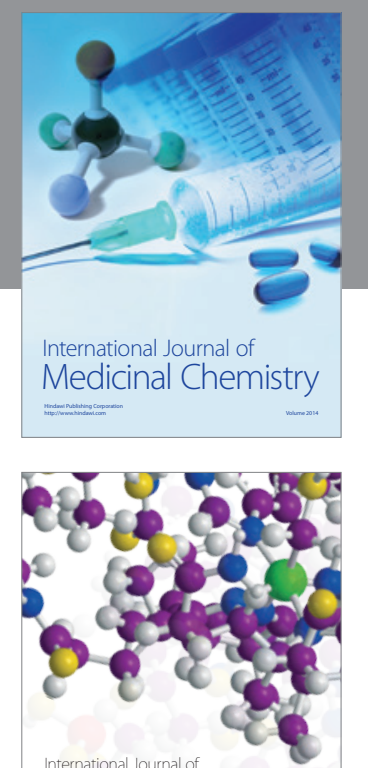

\section{Carbohydrate} Chemistry

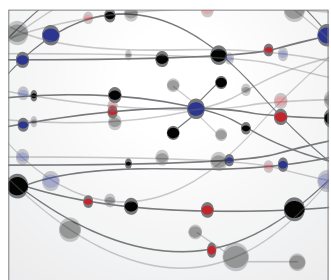

The Scientific World Journal
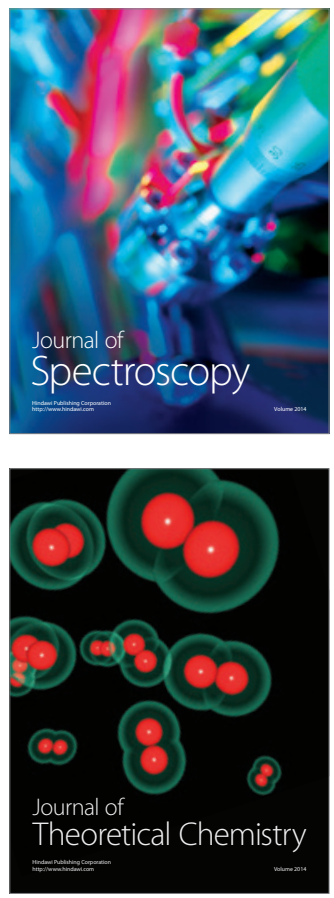
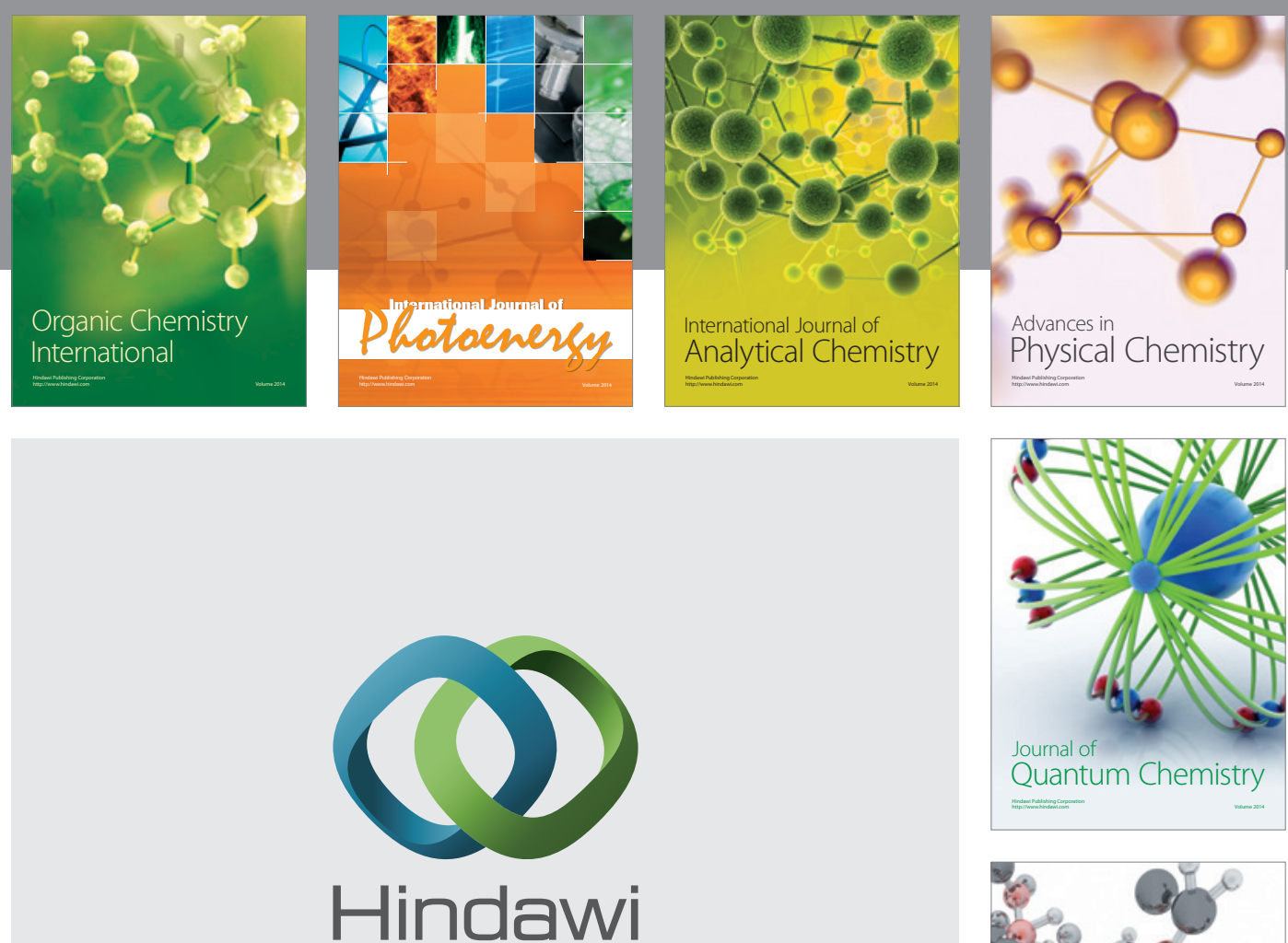

Submit your manuscripts at

http://www.hindawi.com

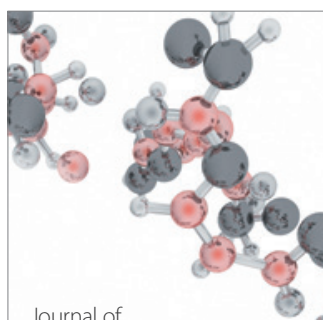

Analytical Methods

in Chemistry

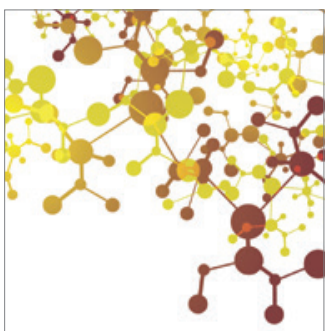

Journal of

Applied Chemistry

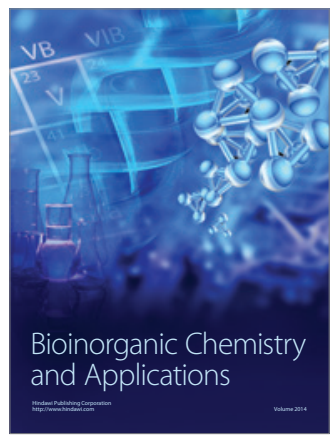

Inorganic Chemistry
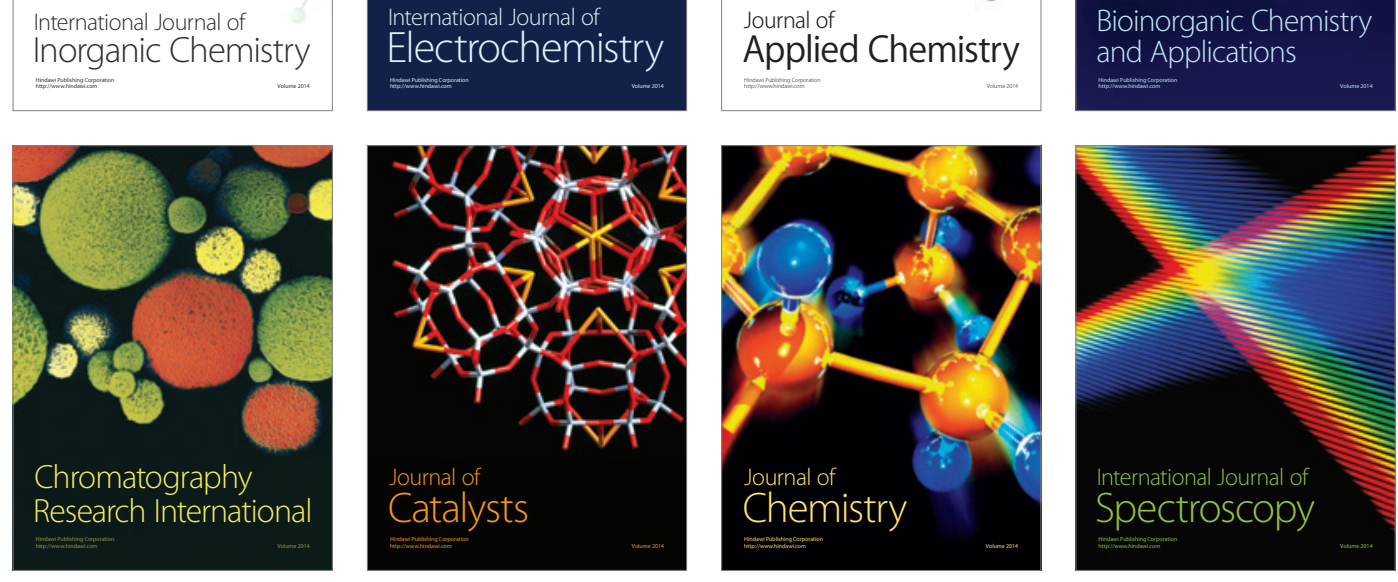